\title{
CIVIL SOCIETY, KONSEP UMMAH DAN MASYARAKAT MADANI
}

\author{
Oleh : \\ Vita Fitria dan Sri Agustin Sutrisnowati \\ MKU-UNY \\ Email : vitafitria08@gmail.com dan sriagustin1961@gmail.com
}

\begin{abstract}
Abstrak : Konsep ummah, civil society dan mayarakat madani mempunyai definisi dan penjelasan yang cenderung mempunyai beberapa persamaan. Ketiganya mempunyai landasan yang sama yakni menekankan pada prinsipprinsip toleransi, desentralisasi, kewarganegaraan, aktivisme dalam ruang publik, sukarela, swasembada, swadaya, otonom, dan konstitusionalisme dan sebagainya. Meskipun demikian, pemahaman dan aplikasi tentang ketiga konsep tersebut tidak bisa dikerucutkan kedalam satu pemikiran yang seragam. Civil society lebih menginduk dari proses sejarah masyarakat Barat. Dalam hubungannya dengan sejarah panjang umat Islam, pola-pola seperti yang tercermin dalam konsep civil society tersebut sudah dibangun oleh Rasullullah ketika di Madinah dengan konsep Ummah, yang tercatat dalam Piagam Madinah. Sementara konsep Masyarakat Madani merupakan suatu istilah untuk memudahkan dan memaknai konsep civil society dan konsep ummah dalam konteks Islam dan Indonesia.
\end{abstract}

Kata Kunci : Civil Society, Konsep Ummah, Masyarakat Madani

\section{Pendahuluan}

Sebagai sebuah konsep, civil society berasal dari proses sejarah masyarakat Barat. Akar perkembangannya dapat dirunut mulai Cicero (106-43 SM) dan bahkan sampai Aristoteles ( 384-322 SM). Mengenai istilah civil society, Cicero lah yang pertama kali menggunakan dalam filsafat politiknya. Di sini civil society identik dengan the state (negara), yaitu sebuah komunitas yang mendominasi sejumlah komunitas lain ( Hikam, 1996:1). Sedang Aristoteles tidak menggunakan istilah civil society, tetapi koininie politike, yakni sebuah komunitas politik tempat warga dapat terlibat langsung dalam pengambilan keputusan (Cohen dan Arato, 1992:84). Namun pada pertengahan abad 18, terminologi ini mengalami pergeseran makna. Negara dan civil society kemudian dimengerti sebagai dua buah entitas yang berbeda, sejalan dengan proses pembentukan sosial dan perubahan-perubahan struktur politik di Eropa sebagai 
akibat dari zaman enlightment dan modernisasi yang sangat berperan menggusur rezim-rezim absolut ( Hikam, 1996:2).

Tidak hanya dalam konsep Barat, Islam pun sudah menerapkan konsep yang identik dengan civil society tesebut, melalui pemerintahan Muhammad saw dengan memproklamirkan Piagam Madinah dengan konsep ummahnya. Dalam perkembangannya, pemaknaan konsep ummah yang identik dengan civil society mengalami perubahan istilah, yakni konsep masyarakat madani. Tulisan ini lebih lanjut akan mengurai tentang konsep civil society, persamaan maupun perbedaanya dengan konsep ummah atau masyarakat madani.

\section{Civil Society : Perkembangan Makna dan Istilah}

Dalam perkembangannya, istilah civil society mengalami pergeseran makna, sejalan dengan dinamika pemikiran dan faktor-faktor yang melingkupi konteks dimana civil society itu diterapkan. Sejauh ini minimal ada lima model pemaknaan, yaitu ( Karni, 1999:21):

1. Civil society yang identik dengan state (negara). Selain Cicero dan Aristoteles, Thomas Hobbes dan John Locke juga memahaminya sebagai tahapan lebih lanjut dari evolusi natural society, yang pada dasarnya sama juga dengan negara. Menurut Hobbes, civil society harus memiliki kekuasaan absolut agar mampu meredam konflik dalam masyarakat dan dapat sepenuhnya mengontrol pola interaksi warga negara. Sedang menurut Locke, kemunculan civil society ditujukan untuk melindungi kebebasan dan hak milik warga negara. Karenanya, civil society tidak boleh absolut, dan harus dibatasi perannya pada wilayah yang tidak bisa dikelola masyarakat, serta memberi ruang yang wajar bagi negara untuk memperoleh haknya secara wajar pula.

2. Adam Ferguson (1767) memaknai civil society sebagai visi etis dalam kehidupan bermasyarakat untuk memelihara tanggung jawab sosial yang bercirikan solidaritas sosial dan yang terilhami oleh sentimen moral serta sikap saling menyayangi antar warga secara alamiah. Lebih jelasnya, civil society dipahami sebagai kebalikan dari masyarakat primitif atau masyarakat barbar. 
3. Thomas Paine (1792) memaknai civil society sebagai antitesis dari negara. Civil societylah yang mengontrol negara demi keperluannya.

4. Pemaknaan yang didasarkan pada sisi "elemen ideologi kelas dominan". George Wilhelm Friedrich Hegel (1770-1831) mengembangkan pemaknaan civil society sebagai entitas yang cenderung melumpuhkan dirinya sendiri. Untuk itulah diperlukan adanya dan supervisi dari negara berupa kontrol hukum, administrasi dan politik. Selanjutnya dikatakan bahwa kenyataannya civil society modern tidak mampu mengatasi permasalahannya sendiri, serta tidak mampu mempertahankan keberadaannya tanpa keteraturan politik dan ketertundukan pada institusi yang lebih yaitu negara. Jika terjadi ketidakadilan dalam masyarakat, atau jika terjadi ancaman terhadap kepentingan universal tentu saja negaralah yang berhak menentukan kriteria kepentingan universal tersebut. Lain lagi menurut Karl Marx (1818-1883) yang menempatkan civil society lebih pada basis material dan dipahami dari sisi produksi kapitalis, menurutnya, civil society adalah masyarakat borjuis, sehingga keberadaannya harus dilenyapkan karena akan merupakan kendala untuk mewujudkan masyarakat tanpa kelas. Sedang Antonio Gramsci (w.1937) memahaminya lebih pada sisi ideologis, dan menempatkan civil society berdampingan dengan negara yang disebutnya dengan political society. Menurutnya, negara akan terserap dalam civil society, sehingga kemudian terbentuklah sebuah masyarakat teratur ( regulated society).

5. Alexis 'De Tocqueville, memaknainya sebagai entitas penyeimbang kekuatan negara, menurutnya civil society tidak apriori subordinatif terhadap negara, sebagaimana yang dikemukakan oleh Hegel, tetapi mempunyai sifat otonom dan memiliki kapasitas politik cukup tinggi yang mampu menjadi penyeimbang untuk menahan kecenderungan intervensi negara.

Sampai saat ini pemahaman para intelektual tentang konsep civil society masih berbeda-beda, tergantung perspektif mana yang diikuti. Yang menggunakan pendekatan Hegelian, lebih menekankan pentingnya kelas menengah dan pemberdayaannya, khususnya bagi sektor ekonomi dan bagi pembangunan civil society yang kuat. Pendekatan Gramscian diterapkan untuk menghadapi hegemoni 
ideologi negara. Dan pendekatan Tocquevellian menekankan pada penguatan organisasi-organisasi independen dalam masyarakat dan pencangkokan civic culture untuk membangun jiwa demokrasi ( Hikam, Paramadina,Vol 1 No 2, 1999:40).

Model Gramsci dan Tocqueville lebih banyak menjadi inspirasi gerakan pro-demokrasi di Eropa Timur dan Eropa Tengah pada akhir tahun 1980-an daripada konsep Hegel yang dianggap terlalu pesimis dalam memaknai civil society. Pengalaman dari negara-negara tersebut membuktikan bahwa dominasi negara atas masyarakat justru akan melumpuhkan kehidupan sosialnya (Karni, 1999:29). Gerakan membangun civil society menjadi perjuangan untuk membangun harga diri mereka sebagai warga negara. Gagasan civil society menjadi landasan ideologis untuk membebaskan diri dari cengkeraman negara yang secara sistemik melemahkan daya kreasi dan kemandirian mereka. (Karni, 1999:29).

Selanjutnya berkembang di Eropa dan menjadi basis kehidupan demokrasi modern adalah civil society model Tocqueville. Civil society ini berlandaskan pada prinsip-prinsip toleransi, desentralisasi, kewarganegaraan, aktivisme dalam ruang publik, sukarela, swasembada, swadaya, otonom,dan konstitusionalisme (Karni, 1999:31).

Upaya penguatan civil society ini kemudian dilakukan di negara-negara Eropa Timur, Amerika Latin, dan negara-negara berkembang lain agar masyarakat dapat bebas mandiri dari intervensi negara yang berlebihan, serta dapat ikut serta dalam melakukan kontrol terhadap negara yang pada umumnya otoriter, sementara masyarakat politik (polotical society) tidak berdaya menjalankan fungsinya secara efektif. Dalam kondisi yang demikian muncul sebuah dilema yaitu antara keterlibatan negara dalam mengatur urusan masyarakat dengan keinginan agar masyarakat mandiri dalam mengatur urusannya sendiri.

Perkembangan saat ini, civil society dipahami sebagai identik dengan masyarakat modern, atau masyarakat yang berkembang di Barat, bukan di Timur atau negara-negara yang sedang berkembang, dan konsep civil society ini tidak beranjak jauh dari konsep demokrasi. 
Diskursus demokrasi, biasanya orang berbicara tentang interaksi antara negara dan civil society. Asumsi dasarnya adalah, jika civil society vis a vis negara relatif kuat, maka demokrasi akan berlangsung. Sebaliknya, jika negara kuat dan civil society lemah, maka demokrasi tidak berjalan. Dengan demikian, demokratisasi dipahami sebagai proses perberdayaan civil society (Rahardjo, Paramadina, Vol 1 No.2, 1999:13).

\section{Islam dan Masyarakat Madani}

Dipandang dari sudut peralihan peristilahan, istilah "madani" biasanya diambil dari kata "madinah", yang digunakan sejak abad lalu dalam arti "civil", beradab. Muhammad Abduh menulis salah satu karangannya dengan judul alIslam wa -l-Nashraniyyah ma'al Ilmu wa al-Madaniyyah (Islam dan Kristen tentang Ilmu dan Peradaban). Republika, 19 Mei 1998 , pernah menjelaskan bahwa secara etimologi masyarakat madani mengandung dua makna, yaitu masyarakat kota dan masyarakat beradab. Jelas mempunyai kedekatan makna dengan istilah asalnya, yaitu "civil society". Sebelumnya, istilah civil society diterjemahkan dengan "masyarakat warga", "masyarakat sipil", "masyarakat modern", "masyarakat kekeluargaan" dan mungkin masih ada terjemahan yang lain. Meskipun masih ada pro dan kontra, istilah "masyarakat madani" ini dirasa lebih pas untuk diterapkan terutama di Indonesia.

Secara keilmuan, istilah tersebut dibawa ke Indonesia oleh Dato Seri Anwar Ibrahim yang ketika itu sebagai Menteri Keuangan dan Wakil PM Malaysia, dalam acara Simposium Nasional pada Festival Istiqlal, 26 September 1995 di Jakarta. Istilah itu sendiri diterjemahkan dari bahasa Arab 'mujtama'madani', yang diperkenalkan oleh Prof. Naquib al-Attas, seorang ahli sejarah dan peradaban Islam dari Malaysia, pendiri sebuah lembaga yang bernama Institute for Islamic Thought and Civilization (ISTAC) yang disponsori oleh Anwar Ibrahim ( Rahadjo, 1999:8).

Meskipun tidak bisa dikatakan sama persis, dan pasti ada beberapa perbedaan tertentu, untuk selanjutnya dari tulisan ini yang penulis maksud dengan masyarakat madani adalah identik dengan civil society. Hal ini untuk 
memudahkan makna dari civil society tersebut dalam konteks Islam atau Indonesia. Konsep tentang civil society pada dasarnya mengandung beberapa masalah dalam penerapannya. Artinya, pengertian dan interpretasi ini berubah dari waktu ke waktu. Tidak hanya berubah dalam dimensi waktu, tetapi pengertian yang dimaksud oleh istilah itu berbeda pada berbagai pemikir kontemporer di masa lalu dan dewasa ini. Itulah sebabnya mengapa persepsi orang tentang civil society berbeda-beda sampai sekarang. Demikian pula pengggunaan istilah tertentu bisa menimbulkan asosiasi dan persepsi yang berbeda. Hal ini tergantung pada informasi dan pengetahuan orang atau kelompok yang bersangkutan.

Mencari padanan istilah masyarakat madani menurut kalangan intelektual kita memang sulit, namun Nurcholis Madjid mampu mendiskripsikan istilah ini dalam perspektif keindonesiaan sangat aspiratif, substantif dan fungsional. Nurkholis menafsirkan bahwa wujud nyata masyarakat madani pertamakali dalam sejarah adalah hasil usaha Muhammad saw. Tindakan nabi untuk mengganti nama dari Yasrib menjadi Madinah bukanlah suatu kebetulan. Di balik itu terkandung makna yang mendalam, yang dalam kontrasnya terhadap pola kehidupan politik jazirah Arab dan sekitarnya adalah fundamental dan revolusioner. Perubahan nama tersebut seperti semacam isyarat langsung akan adanya definisi proklamasi atau deklarasi, bahwa di tempat baru itu hendak terwujud suatu masyarakat yang teratur ( Madjid, 1999: 17). Masyarakat Madani pada hakekatnya adalah reformasi total terhadap masyarakat tak kenal hukum Arab Jahiliyah dan terhadap supremasi kekuasaan pribadi seorang penguasa seperti yang selama ini menjadi pengertian umum tentang negara. Dasar-dasarnya diletakkan oleh Nabi kemudian dikembangkan oleh para khulafaur rasyidun dengan membentuk sistem pemerintahan. Hasilnya ialah suatu tatanan sosial politik yang menurut Robert N. Bellah -seorang sosiolog Amerika Serikat- sangat modern, bahkan ia katakan terlalu modern untuk zaman dan tempatnya ( Bellah: 1991). Konstitusi Madinah (Piagam Madinah) merupakan dokumen pertama dalam sejarah umat manusia yang meletakkan dasar-dasar pluralisme dan toleransi. Dalam piagam tersebut ditetapkan adanya pengakuan kepada semua penduduk Madinah, tanpa 
memandang perbedaan agama, suku bangsa sebagai anggota umat yang tunggal, dengan hak-hak dan kewajiban yang sama ( Madjid, 1999:22).

Suatu kenyataan yang tidak bisa dipungkiri, bahwa apa jawaban yang harus kita katakan jika ada pertanyaan, faktor apa sesungguhnya yang menjadi dasar bagi perubahan masyarakat Yasrib dari keduniawian menjadi peradaban, apa yang mengubah masyarakat Arab dari Jahiliyah ke masyarakat berperadaban? Satu-satunya jawaban adalah "Islam". Karena sejak Islam muncul dan berkembang di sana, meskipun masih dalam tahap awal, transformasi dan perubahan masyarakat terjadi secara besar-besaran, baik dilihat dari sudut pandang keagamaan (lebih rasional) maupun kehidupan sosial politik budaya dan ekonomi (lebih berperadaban). Dalam bahasa agama, salah satu fungsi Islam adalah membawa masyarakat dari alam kegelapan (al-dhulumat) ke alam yang terang benderang (al-nuur). Hal ini banyak sekali disebut dalam Alquran dengan kalimat yakhruju minal-dhulumat ila al-nuur.

Islam tidak bicara tentang bentuk-bentuk pemerintahan secara detail, menurut Bahtiar Effendy, Islam pada dasarnya hanya berperan sebagai panduan nilai, moral dan etika dalam bentuknya yang global. Demikian pula ketika kita bicara tentang hubungan antara Islam dan demokrasi, Islam dan politik, serta Islam dan masyarakat madani. Alquran hanya memberikan wawasan, bukan konsep tentang masyarakat madani secara detail (Effendi, 1998: 82). Untuk itu, konstruksi bangunan masyarakat madani yang ada dalam suatu negara pasti akan berbeda dengan negara lain. meski harus dikatakan bahwa prinsip dasarnya adalah sama, berperan sebagai inti dari bangunan masyarakat madani atau bangunan politik yang demokratis ( Effendi,1998: 82).

Islam memberi batasan tegas tentang prinsip-prinsip yang terkandung dari masyarakat madani yaitu: prinsip keadilan, persamaan dan musyawarah (demokrasi). Di sinilah sebenarnya kita dapat mengaitkan dengan jelas hubungan antara Islam dan masyarakat madani. Kebebasan relatif yang dimiliki bangunan masyarakat madani, fungsi kontrol yang dikembangkan oleh lembaga yang dapat disebut sebagai institusi civil society merupakan penerapan lanjutan dari konsepkonsep keadilan, persamaan dan musyawarah tadi ( Effendi :83). 


\section{Masyarakat Madani dan Konsep Ummah}

Sebagaimana telah dijelaskan di atas, dalam hubungannya dengan sejarah panjang umat Islam, pola-pola seperti yang tercermin dalam konsep masyarakat madani tersebut sudah dibangun oleh Rasullullah ketika di Madinah dengan konsep Ummah nya, yang tercatat dalam Piagam Madinah.

Ada beberapa definisi tentang ummah, banyak disebutkan dalam ayat-ayat Alquran, seperti yang tertulis dalam Surat Ali Imran: 104, disebutkan, "Hendaklah ada di antara kamu segolongan umat yang menyeru kepada kebaikan, menyuruh kepada yang ma'ruf dan mencegah dari yang mungkar, merekalah orang-orang yang beruntung". Ummah bukan semata entitas beku yang tersatukan oleh perekat tertentu, namun suatu komunitas yang memiliki visi etis, profetik dan transformatif. Dan Ummah juga mempunyai muatan yang dinamis. Ummah yang dimaksud bisa berupa sekelompok tertentu dalam masyarakat, organisasi, pemerintah atau negara, sebagai bagian dari masyarakat.

Dalam Piagam Madinah ( Maarif: 1988) ummah menjadi prinsip kunci untuk memahami komunitas warga Madinah. Konsep inilah yang menjadi perekat utama dalam komunitas negara Madinah. Aplikasi ummah dalam negara Madinah sarat dengan visi etis kehidupan bermasyarakat, seperti toleransi, solidaritas sosial, egalitarianisme, taat asas, keterbukaan, partisipasi, berketuhanan dan sebagainya.Ummah juga ditugasi fungsi kontrol untuk menyeru kebaikan dan mencegah kemungkaran ( Karni, 1999:66).

Dalam sistem kekuasaan di Madinah ini ada prinsip timbal balik, di mana rakyat mempunyai konsekuensi untuk menaati pemimpinnya sepanjang pemerintahan berjalan adil dan tidak maksiat kepada Tuhan, dan rakyat juga wajib mengkritik bahkan memberhentikan bila pemimpin tidak bisa diharapkan lagi. Sebaliknya, penguasa yang mempunyai hak menikmati ketaatan rakyatnya, berkewajiban untuk menjamin kemaslahatan rakyat. Keberadaan Muhammad sebagai pemimpin yang juga seorang nabi, semakin mengokohkan posisi kepemimpinan dan semakin disegani rakyat. Namun posisi itu tidak membuatnya otoriter, justru ia pakai untuk mengembangkan iklim politik yang transparan dan 
terbuka, sehingga rakyatnya memiliki kesadaran politik dan daya kritis yang tinggi. Ringkasnya, ummah dan penguasa bisa bekerjasama secara proporsional dan harmonis namun tetap saling kritis untuk bersama-sama mewujudkan tatanan yang damai, adil, terbuka demokratis dan berperadaban.

Konsep semacam inilah yang mendasari akan harapan terwujudnya civil society, atau masyarakat madani terutama di negara-negara yang sedang berkembang termasuk Indonesia. Dalam perjalanannya, konsep-konsep pemaknaan maupun persyaratan terwujudnya masyarakat madani berkembang sesuai dengan kondisi, situasi dan kebutuhan dari masing-masing negara yang menerapkannya.

\section{Profil Masyarakat Madani}

Ada beberapa karateristik yang bisa dikatakan sebagai ciri-ciri dari masyarakat yang dicita-citakan (masyarakat madani). Karateristik tersebut adalah : a) masyarakat demokratis, b) masyarakat yang menjunjung dan menghargai tinggi HAM, c) masyarakat yang mempunyai komitmen tinggi bagi tegaknya hukum d) masyarakat yang profesional (Umar, Jurnal Ta'dib, vol.3 no.3, 1999:16).

Jadi masyarakat madani ini merupakan wujud dari harapan masyarakat di masa depan. Salah satu elemen penting terwujudnya masyarakat madani adalah “civilize society" (masyarakat yang berbudaya). Artinya, masyarakat sendiri harus menunjukkan sikap dan derajat budaya tertentu. Kuncinya, masyarakat tidak hanya diwarnai oleh pemerintah atau penguasa, tetapi oleh berbagai kekuatan masyarakat yang dimiliki masyarakat tersebut. Masyarakat yang demikian tentunya mempunyai tingkat derajad toleransi yang tinggi terhadap tindakan orang lain, didukung oleh wawasan yang luas yang dimilikinya serta sikap dan perilaku terhadap norma-norma yang berlaku dalam tatanan masyarakat. Ini menunjukkan bahwa masyarakat madani juga harus memiliki tingkat moralitas yang tinggi. Munculnya kesombongan serta selalu mengedepankan diri sebagai yang terbaik harus dihilangkan, karena egoisme semacam itu hanya akan menghasilkan tekanan-tekanan bagi orang lain (Djohar MS, 2003: 167-184). 
Dalam ceramahnya yang berjudul "Islam dan Pembentukan Masyarakat Madani”, Anwar Ibrahim mengemukakan sebagai berikut (Ibrahim: Rahardjo, Paramadina, 1999:23) :

Yang dimaksud dengan masyarakat madani adalah sistem sosial yang subur yang berlandaskan kepada prinsip moral yang menjamin keseimbangan antara kebebasan perorangan dengan kestabilan masyarakat. Masyarakat mendorong daya usaha serta inisiatif individu baik dari segi pemikiran, seni, pelaksanaan pemerintahan mengikuti undang-undang dan bukan nafsu atau keinginan individu menjadikan keterdugaan atau predictability serta ketulusan atau transparency sistem.

Konsep masyarakat madani tersebut bukan hanya merupakan konsep ideal, tapi juga berlandaskan empirik. Bisa dipahami bahwa masyarakat madani adalah masyarakat yang bermoral, masyarakat yang menjamin keseimbangan antara kebebasan perorangan dan kestabilan masyarakat, masyarakat yang mampu mendorong daya usaha dan inisiatif individu. Masyarakat yang seperti itulah yang mampu mendorong investasi ( Ibrahim, Rahardjo, Paramadina 1999:23).

\section{Relevansi Civil Society dengan Konsep “Ummah” Masyarakat Madinah}

Ada beberapa persamaan dan perbedaan antara wacana civil society dan konsep ummah yang diterapkan oleh Rasulullah saw (Karni, 1999: 85-102) :

1. Dari segi watak dasar, kedua konsep tersebut mempunyai kesamaan sifat, yakni terbuka, dinamis dan berorientasi non-utopis. Bedanya, sifat keterbukaan dan dinamika makna ummah jauh lebih luas ketimbang civil society, sementara watak non-utopis civil society lebih menonjol karena umumnya ia terbentuk dari realitas empirik, sementara ummah tidak sepenuhnya empirik karena mengandung muatan-muatan normatif yang terderivasi dari ajaran agama.

2. Dilihat dari latar belakang munculnya konsep, civil society muncul dari latar belakang yang beragam dari situasi masyarakat yang terancam kacau akibat menguatnya individualisme dan tajamnya benturan kepentingan. Sementara ummah, situasi konflik yang terjadi antar suku di Madinah, krisis moral dan spiritual masa itu sangat melatarbelakangi munculnya konsep ummah. Ini 
merupakan kesamaan antara kedua konsep tersebut yang sama-sama berakar dari konflik dalam masyarakat. Perbedaannya pada keberadaan dan fungsi negara. Dalam konsep ummah, institusi negara yang dibentuk masih sederhana, dan kinerja masyarakat dinilai lebih penting daripada kinerja negara. Sementara negara menurut Hobbes, keberadaannya dipandang sebagai suatu keharusan yang mempunyai kekuatan absolut dan memegang peranan penting dalam mengelola masyarakat.

3. Hubungannya dengan Agama, civil society merupakan konsep sekuler yang dalam perjalanannya mendapat sentuhan dan legitimasi agama. Sedangkan ummah adalah konsep normatif keagamaan yang dalam prakteknya dicoba diobjektivikasikan dalam realitas empirik.

4. Unsur Perekat kesatuan civil society adalah kewarganegaraan. Sedangkan perekat ummah cukup beragam, bisa kesamaan agama, kesamaan generasi, kesamaan karakter etik, kesamaan bangsa dan sebagainya. Hanya saja, dimensi agama lebih dominan mewarnainya.

\section{Penutup}

Secara mendasar dapat dikatakan, bahwa civil society dan konsep ummah masyarakat Madinah, sesungguhnya lahir dari keragaman situasi dan kondisi masyarakat yang ada. Bentuk keragaman tersebut terbangun di atas carut marutnya suatu masyarakat yang terkungkung individualisme, kekerasan dan ketidakadilan dalam suatu masyarakat, sehingga mengharuskan munculnya suatu konsep yang didasarkan atas kemanusiaan universal.

Konsep tentang civil society pada dasarnya mengandung beberapa masalah dalam penerapannya. Artinya, pengertian dan interpretasi ini berubah dari waktu ke waktu. Tidak hanya berubah dalam dimensi waktu, tetapi pengertian yang dimaksud oleh istilah itu berbeda pada berbagai pemikir kontemporer di masa lalu dan dewasa ini. Itulah sebabnya mengapa persepsi orang tentang civil society berbeda-beda sampai sekarang. Demikian pula pengggunaan istilah tertentu bisa menimbulkan asosiasi dan persepsi yang berbeda. Hal ini tergantung pada informasi dan pengetahuan orang atau kelompok yang bersangkutan. 
Perbedaan-perbedaan konsep yang ada dalam civil society dan ummah tidak terjadi dalam aspek yang krusial berkaitan dengan demokratisasi. Perbedaan-perbedaan tersebut lebih bersifat fungsional dan kontradiksional. Kalau mungkin bisa berpotensi konflik, terutama yang berkaitan dengan agama, dalam sejarahnya hal itu masih bisa dikelola menjadi kekuatan simbiotik.

\section{DAFTAR PUSTAKA}

Bellah, Robert N. 1991. Beyond Belief, Barkeley: University of California Press.

Budiman, Arif (ed.). 1990. State and Civil Society, Clayton: Monash Papers on Southeast Asia.

Cohen, Jean L. dan Arato, Andrew. 1992. Civil Society and Political Teori, London : MIT Press.

Effendy, Bahtiar. 1998. Islam dan Negara: Transformasi Pemikiran dan Praktik Politik Islam, Jakarta: Paramadina.

Hikam, Muhammad AS. 1996. Demokrasi dan Civil Society, Jakarta : LP3S.

, 1999. "Wacana Intelektual Tentang Civil Society di Indonesia", dalam jurnal Paramadina, vol.1, No.2, tahun 1999.

Ibrahim, Anwar. 1999. "Islam dan Pembentukan Masyarakat Madani", dalam M. Dawam Rahardjo,"Masyarakat Madani di Indonesia" dalam Jurnal Paramadina, vol.1, no.2.

Karni, Asrori S. 1999. Civil Society \& Ummah, Jakarta : Logos.

Maarif, A. Syafi`i. 1988. Islam dan Politik di Indonesia pada Masa Demokrasi Terpimpin (1959-1965), Yogyakarta: Suka Press.

Madjid, Nurcholis. 1999. "Masyarakat Madani dan Investasi Demokrasi: Tantangan dan Kemungkinan", Pengantar untuk Ahmad Baso dalam Civil Society versus Masyarakat Madani: Arkeologi Pemikiran Civil Society dalam Islam Indonesia, Bandung: Pustaka Hidayah.

MS, Djohar. 2003. Pendidikan Strategik, Alternatif Untuk Pendidikan Masa Depan, Yogyakarta: Lesfi. 
Rahardjo, M. Dawam. 1999. "Masyarakat Madani di Indonesia, Sebuah Penjajakan Awal", dalam jurnal Paramadina, vol 1, no 2.

Umar, Bukhari. 1999. "Pembinaan Masyarakat Madani dan Konstribusi Pendidikan Keluarga" dalam Jurnal Ilmiah Ta'dib, vol.3, no.3, September- Desember. 